\title{
電氣爐新操業法こしてのバリウム 媒熔劑の使用に就で
}

面 員大垣 梅 雄

\section{I. 緒}

宙

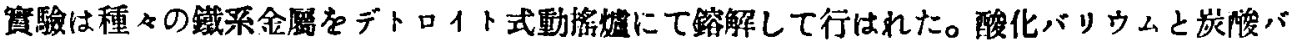
リウムの混合物を注出約牛封䦚前に添加する洔は單に製品を改良するのみならす、煺の陵性耐 火材の生命を大に延長することが發見された。後にそのことは熷中のバリウム化合物がフーっ を安定し月つ調整するによると覞察さるっに至つた。

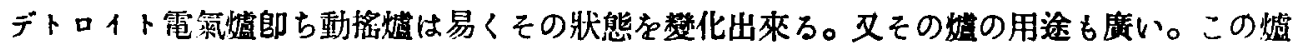
は量の多少に拘らす特称合金の豁解に於て失敗無しに手早く成分を棥へることが出來るのて目 的製品の物理的及び化學的性質を非常に狹い範圍に限定することが出來ろ。キューボラやその

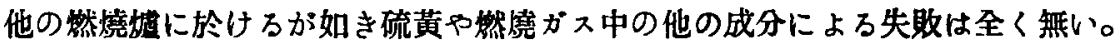

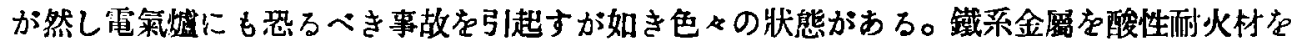
使用して高温に鎔解する必要ある場合には常に珄素が垍し、即ち金屬中に入り、及 $\mathrm{SiO}_{2}$ を吸 收して金䪅を惡化せしめる。その間に如何なる反應が起るかと云ふ考ふべき討論が行はれた

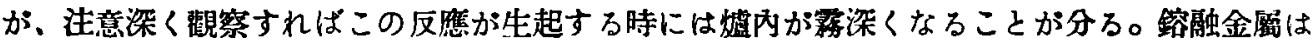

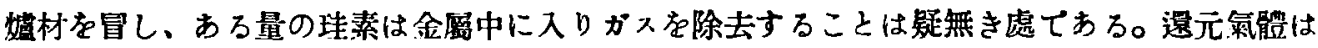
特にこの反應を進め、發生期の珠素を生じ、金愿中の含有炭素量を相當に低下する。

上記の反應は金臨に有害でるから出來る限り避けるべきでおる。次に記するが如き特に用

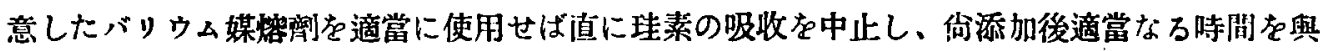

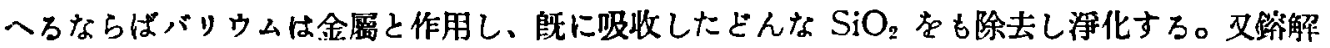
期に使用せば Si の反應在少しも生起しない棓にするだらう。

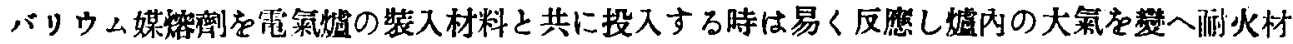

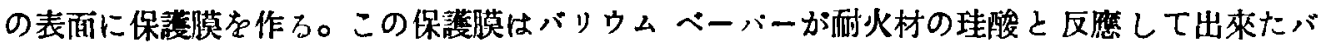
リウムガラスである。このガラスは露出せるトリヂマナイト結晶の緣に鋸㐘狀に瀜着し脈石 の如くくつつきボンド (bond) として耐火材を丈夫にする。使用するバリウムの量は非常に少 いが伐材をガラス状にするには十分である。このがラス狀物質は每回の裝入時に少量の類似 治噔 (homeopathic) の一服を投することにより保持される。 
高温なる電氣爟中に於てバリウムが酸性贱材に作用しボンドとして働くと如何なる理由によ

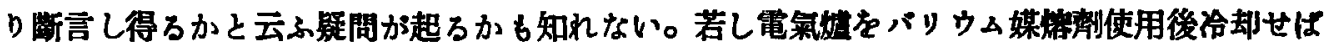

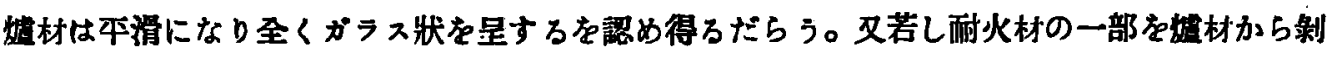
離し检鏡すろならば上記の作用を䠐繁し得るだらう。即ち耐火材界は電氣嘘にバリウムを使用 することにより、ある程度進步發達出來る。理石煉瓦はボンド材として、カルシウム化合物の 代りにバリウム化合物を使用し紫造されて居る。この新煉瓦を現在の設備によりその價檤を試 驗したるに、最も不利な狀態に於ても䢃開されなかつた。

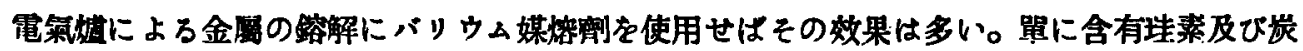
素の量を變化せしめないのみならす多くの爽椎物、硫黄、酸素、その他を除去し浮化する。向

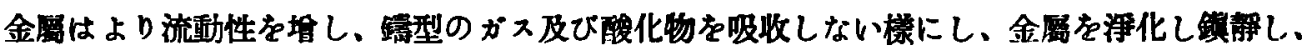

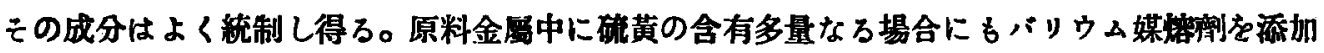

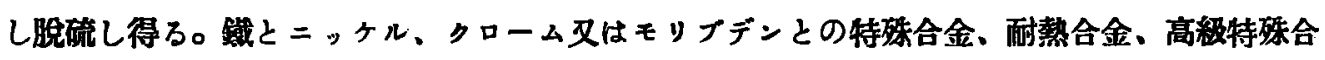

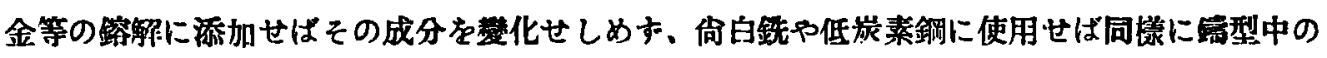

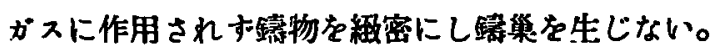

\section{II. バリウム媒熔割の成分}

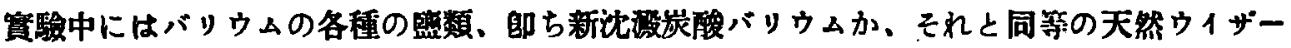
ライト(Witherite), 硫酸バリゥム(粗いそして精製した)、酸化バリウム(市場にある純轱な ろもの)、トリバリウムフルミネート(tribarium alminate) その他を使用した。重要なる賽臨

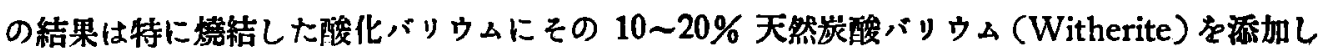
た混合物が最も能率を良く再現し得る結果を興へた。この燒結した酸化バリウムはカタライ ザーを使用する特許の方法によりその政解點を低下し得る。それは泼中に於て反應を進行せし めろ處のある程度不純物を含む綌解點低き普通の酸化物であろ。この酸化物を炭酸バリウムに 混合し爈內に投入する時は上記の反慰を進行せしめる。

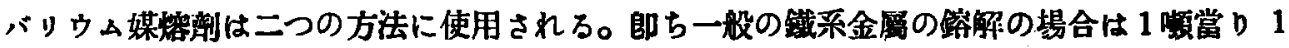

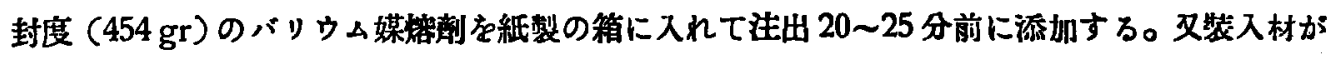

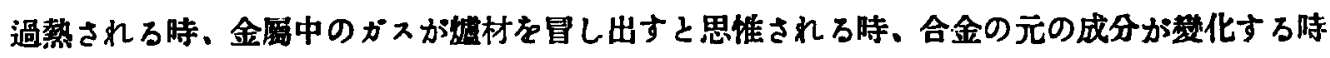

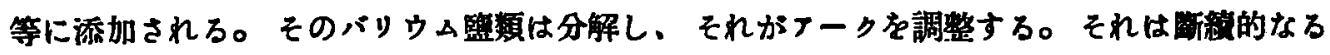

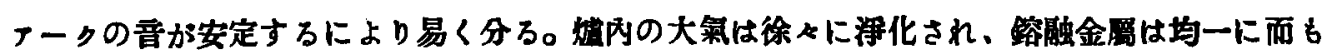
錤静される。若し添加後 10 分にして㥺內反應が鎮靜されない場合は尚 1 封度を添加する必要

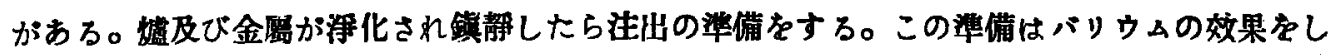
て全からしめんが篇には出來るだけ手早く行はねばならない。 


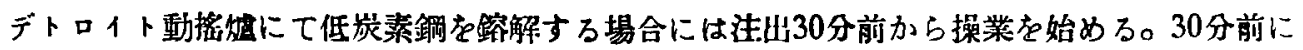

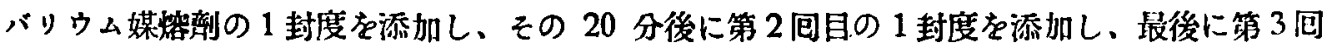
目の 1 封度を尚 10 分後に添加する。

若し炭素を添加する必要がある場合には金虚が鎔解した時に（約 $200 \mathrm{kWh}$ が消費された

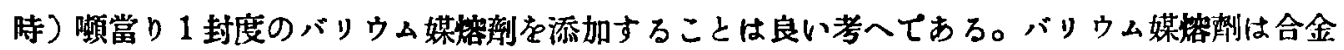
中に宸素の熔解するを助長しこの吸收能率を坦大する。

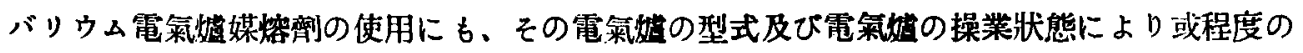
相造はある。デトロイト式動㩲爐を使用する場合はスラグ無しに操業さろつ故バリウムは何等

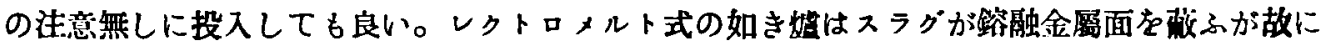

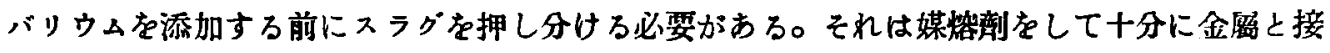

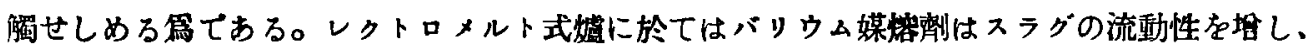
贱壁は洗はれ、金虏中のスラグ含有も少くなる傾向がある。

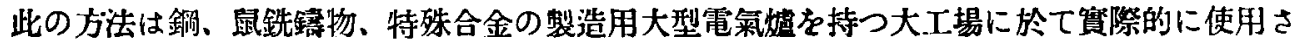

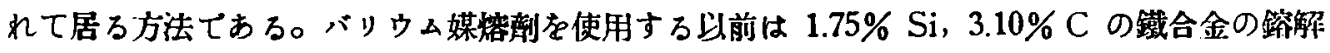

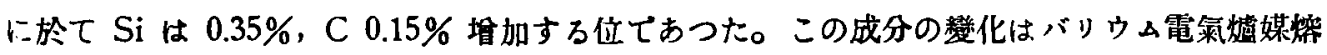
刺の使用により有效に適切に中止された。脫硫の程度は勿論その狀態とその合金にもよること であるが $0.085 \sim 0.091 \%$ S のものが 0.065〜0.071\%に低下した。

\section{III. 結論}

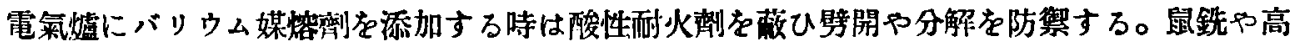

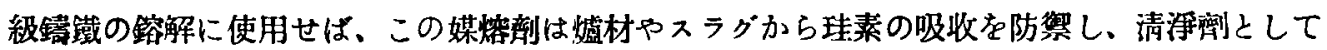

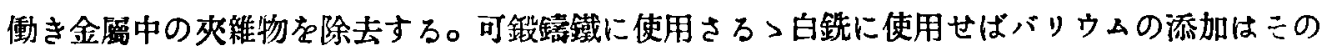

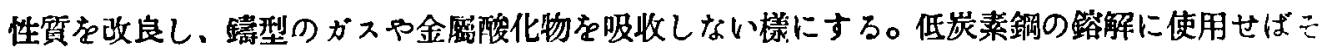
の性質を改良することは前記の通りであろ。硫黄高きぺリング鐵合金に添加せば硫黄は幾分

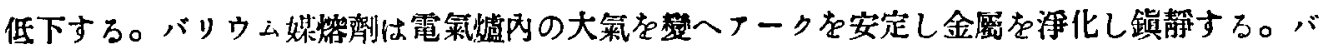
リウムは電氣爐の或る型式のものに於てはスラグを調節し粘性を減じ、墒品中にスラグの含有 さろつをさけ㯭壁にスラグの附着するを妨げる。

\section{IV. 討論}

Clyde E. Williams：私は Baernstein 氏に酸化バリウムが鋼の過䍝元を訂正すると云は れる化學的根據につき御同ひ致し度い。

M. A. Baernstein：珪酸バリウムは $2,600^{\circ} \mathrm{F}\left(1430^{\circ} \mathrm{C}\right)$ に於て流動性良くスラグが嘘忉を 留すことを防敏するによります。 
John M. Mckinley：惐る者は結局珠酸バリウムの硝子狀物資は出來ないと云ふ考人方方

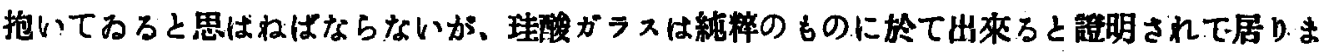
す。若しそれが本當なれば耐火材中に又は炏国の加熱に起万新らしい队部の狀態が洏火材に全 然新なる影管を與へろが如き操作をしてどんな結果になるかは必然的に決まることですま す。その出來たガラスは私見を云ふならば、㠊材に含まれる一般の耐火性スラグが不等方性の 狀態にあるに数し、仡度等方性なろ简吡なるがラスになつて居る々思惟されるのであります。

Clyde E. Williams: 何故较化バリウムが耐火材に效果があるかは分つたが、バリウム化 合物が冾金舅上の之等の困難を如何にして解決し得ると御考へになるか著者に御同ひ致し度い と思ふ。

M. A. Baernstein：此の方法の初めにも。又その過程に於ても既に御锶の通り耐火材に就

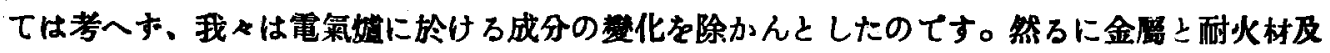

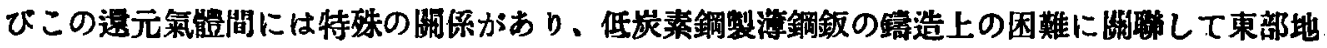
方にて此の問題に通雨したのです。そこで我等はこの酸化バリウムの混合物 1 封度を注出30分 前に投入し、20 分後に尚 1 封度を添加し、尚 10 分後に第 3 间目の 1 封度を添加し㠊を棌化出 來たのでります。添加の洔機は選ばねばならないが操業者は媒螾剖の投入に熟練し通當なる 時機を見分ける滕になるものであります。或ろ鋼會社では酸化バリウムを取鍋中に投入する時

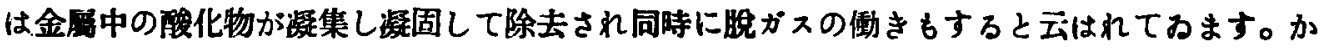
くして淨化作用が㟔來ろのであります。

Louis Navias：㞸酸バリウムを加槷する時は炭酸マグネシウム、炭酸カルシウムを加熱す ろ場合の如く炭酸ガスの上昇により固䯏狀の酸化物に崩懐せす、炭酸バリウムのほんの一部は 酸化バリウムになり、炭酸バリウムと酸化バリウムは嫄け合ひ液狀になるのであります。私は

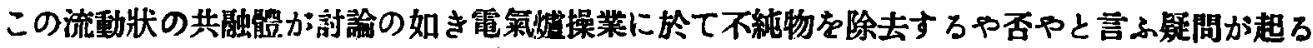
のであります。

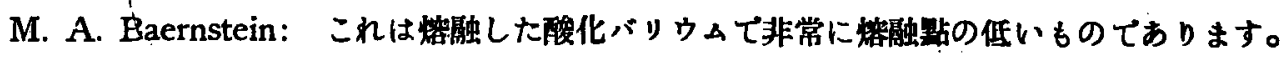
接觸反應により浓體となり嫬外に注出されます。酸化バリウムは古くは炭酸バリウムから㱔造 しました。この方法にては炭素を少量添加しても57〜58 時間を要しますか、烛け易い氣孔度 高い腰化バリウムが得られます。然し水に溶け易いのてす。我々は全然異なつた㱔品を造つて 居ります。我々は最も一般的バリウム原料である硫酸碳、重晶石から直接に㱔造して居ります。 我くは塊のまつ燒結し液狀にして反應を起さしめて居ります。それは $1800^{\circ} \mathrm{F}\left(1000^{\circ} \mathrm{C}\right)$ に於 て嵝融し酸化物の含有される場合には直ぐスラク゚になります。

Albert E. Rhoads (通信によろ)：私は一つの批評炎したいと思よ。本女の初めに或人は：

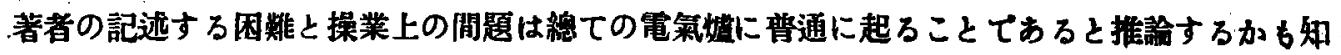


れません。勿論これ等の問題が起らない栐な設備を指しては居りませんが、その他の場にはこ れ等の問題は局部的な狀態によりて起らものであります。所謂これ等の問題は丁度興味あろ問 題であるが、嘘の裝入物の性質、使用される爈材の性質、他の局部的狀態により招來するもの で先天的ではないものであります。多くの嫁の使用者はこの時機を誤らざれば皆良結果を示し て居ります。勿諭その時機上外に使用する必要はない6のてす。屹度確賽な高級金荗を慗造し

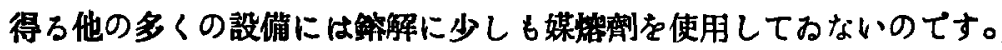

R. H. Mckee：私はバリウムは有毒であろかどうかと云ふことに關して調查し、バリウム は非常に有毒なるを知つたのです。祭者はパリウム監を時に䒚用に供して居ります。

Colin G. Fink: X 光線の作用ですか。

R. H. Mckee：否私は焀け易いバリウム監化物の如き䦗類に州して云ふのてあります。或 フランスの物理學者はバリウム鼠化物の $7 \mathrm{~g}$ を服用したが非常に過度に過ぎてその影糸は丁 度乳狀酸化マグ・シゥムを服用したと同橙てありました。私は個人的にはそのことを何とも考 へてわないが、私の云はんとするところは非常なる毒物であることであります。以上 